\title{
The Preparation of Governmental Organizations of Rasht in Dealing with Natural Crises with Emphasis on Crisis Management Components
}

\author{
Seyed Ali Hosseini (Ph.D) \\ . Assistant Professor of Department of Geography, Payame Noor University, Tehran. Iran \\ Roqieh Heydari (M.A) \\ Geography- Urban Planning, Payame Noor University, Rasht Branch, Guilan, Iran
}

Ali Hayati (M.A)

Farhangian University, Shahid Beheshti Campus, Zanjan, Iran

\section{Fatemeh Heidari (M.A)}

Geography- Urban Planning, Payame Noor University, Rasht Branch, Guilan, Iran

DOI: 10.6007/IJARBSS/v3-i10/278 URL: http://dx.doi.org/10.6007/IJARBSS/v3-i10/278

\begin{abstract}
Increasing of natural disasters over the past decade has led to a catastrophe, due to the large volume of lives and property losses and not having any program. In this context, the appropriate response to these disasters requires planning, forecasting, and using unexpected events prevention methods; the role of governmental organizations is more important as the supporters of citizens.This study aimed to evaluate the status of organizations' preparation in the field of unexpected events in order to reduce the damage caused by natural disasters and provide effective service. Therefore, the factors affecting the preparation are very important, especially in responsible organizations. This study was a descriptive - analytical research. A number of 50 organizations were assessed in terms of preparedness against disaster. Using a researcher made questionnaire, the data was gathered and analyzed by SPSS. The findings of this study showed that the preparedness of governmental organizations in Rasht has not the necessary capabilities; and there was a significant relationship between the characteristics of organizations and the amount of crisis management components.
\end{abstract}

Keywords: Crisis Management, Environmental Disasters, Preparedness, Government Organizations, Rasht 


\section{Introduction}

The crisis is the mismatch between needs and resources. This means that in normal situations, there is a balance between community needs and available resources and capabilities; due to the specific conditions that are imposed on the community, with the emergence of crisis situations that is the result of abnormal and unexpected occurrence of natural and non-natural events such as floods, earthquakes, major storms, wars, and etc., there will is not a balance between needs and resources anymore. Crisis management means restoring the balance between resources and needs. But in the scientific definition, crisis management is a systematic knowledge and a process that tries to prevent the occurrence of accidents, if occurred, it is going to deal with them and reduce their effects, and finally, it tries to rebuild after the crisis subsides ( Hataminrjad and et.al, 2006: 61)

Natural hazards are defined as security threats; because they are synonymous with lack of control, uncertainty, and unpredictability (Sturm \& Oh, 2010: 155). Also, crisis is a natural or non-natural event that dealing with it requires beyond the capabilities of local resources and neighboring communities, states, and national boundaries should help to solve the problem.( Schwenk, et al,2005:233). Therefore, preparation is one of the main stages of crisis management. (Mousavi, 2009: 2); and it is a series of policies and actions taken by the individuals before the accident for the settlement of food reserve, water, medical supplies, temporary shelter, energy, response strategies, crisis response exercises, and etc.(TFQCDM / WADEM ,2002 : 44). The key of real preparation for the crisis is training and improving the human resources that could be achieved by holding workshops, short courses, and training the health workers before the occurrence of a natural disaster(Calderon , 2010: 7130) .

Previous studies confirmed that the crisis management requires formulating a framework or plan. Proper planning and preparation largely reduce the damage and duration of great crisis (Hosseini, et al, 2013 : 1219 ).So, the purpose of crisis management is not creating a set of plans; rather, it aims to prepare the organizations to think creatively on unexpected issues for taking the best decision in the times of crisis( Pearson \& Mitroff, 1993: 59).

In their study, CD and EF (2004) tried to identify some of the barriers to preparedness in emergency sectors. They found that these barriers can be either internal such as lack of special equipments and training the behavior in crisis times, or it can be external such as insufficient knowledge and lack of sufficient cooperation between hospital parts (AF, DM, 2004). In his study (the clusters of preparedness), Austin (2012) tried to assess the amount of preparedness in community-based organizations. He identified seven new preparedness clusters that play an important role in enhancing the crisis preparedness of the governmental organizations. Organizational preparedness activities include improving emergency response plans, training the personnel to respond appropriately in the crisis time, providing the necessary equipment and facilities, exercising various preparedness actions, and etc.( Austin, 2012: 383).

Using qualitative research methods such as interviews with a sample consisting of three specialists in the field of disaster preparedness and response, Duarte and Haniz (2006) answered to three questions. First, what kind of method should be used in the education of crisis in nursing school courses? Second, which population should be trained in the crisis courses? And third, which information is necessary for the educational needs of nurses in the field of crisis preparedness? They analyzed the interviews and found that the used method 
mainly depend on the desired course. Regardless of the used method, an organization should hold meetings to discuss on problems. The courses can be taught by several methods such as online courses, compound courses, sound simulation exercises with the highest quality, and other combined strategies. The best way to respond to a crisis is using a series of different fields with different capabilities. The training should also address the individuals from different disciplines to achieve the educational goals of a community, a region or a country. In relation to the third question of this study, they concluded that the population should have both knowledge and ability to function about a limited set of capabilities in response to a crisis. Due to the different needs of different learners, designing curriculum is important for their involvement and stimulating their growth and development.

According to Greenberg et al (2002), after a critical incident, it is possible many patients to be introduced to the area's hospital wards during a short period of time; therefore, preparedness level of hospital emergency services in response to disaster is very important(Greenberg, et al , 2002: 273). Despite the fact that we live in the age of technological innovation, in recent years, the frequency, severity, and impact of natural disasters has led to thousands deaths and losses of properties extensively in the worldwide. In recent decades, the reasons for these results are the increase in global population, developments such as urbanization, using vulnerable regions, and changes in the environment(Kangabam,20102).

There have always been natural and non-natural disasters affecting the performance of organizations, employees, suppliers, customers, and other organizational infrastructure. Therefore, organizations and firms should be more concerned about the natural and nonnatural crisis. Continuation of operations planning can be beneficial to organizations that are experiencing crisis. Such Continuation of planning can save organization in difficult conditions of crisis. (Duncan, Yeager, 2011). In fact, continuation of planning is a tool that helps organizations remain in their work in serious conditions and not be weakened.

The crises and disasters are essentially events with low-possibility but high impact that threaten the life of an organization "(Duncan et al, 2011: 136). Therefore, continuation of planning should be considered by the organizations for issues such as facilities, communication, supply, databases, and human resource.

With an area of about 10,240 hectares and 104 urban districts, Rasht is one of the most vulnerable cities of Iran in terms of crisis management planning and dealing with disasters such as earthquakes, floods, and snow (Hosseini, et al, 2013: 66). Thus, comprehensive planning in crisis management seems absolutely necessary in this city (Ziyari and Shabani, 2011: 2).

Regarding the items mentioned above and considering Rasht is one of the large cities in the North of Iran, with high population density and old texture, and it is one of Iran's most vulnerable cities, comprehensive planning in crisis management is necessary in this city and the preparedness of governmental organizations as supportive and protective forces for citizens is more important. Considering the main purpose of "checking the status of organizations preparedness against disaster", the study aims to answer to these questions: What is the status of preparedness in governmental organizations of Rasht? How different are the component of crisis management - structure management, preparation, coordination, planning, training, and background information- according to the type of organization? 


\section{The study area}

Rasht is one of the great cities of Iran. This metropolis is also the largest and most populous city among the three provinces of Caspian Sea -Mazandaran, Gilan, and Golestan- in the north of Iran. This city is at 49 degrees 36 minutes east longitude and 37 degrees 16 minutes northern latitude (Abbas Zadeh et al, 4:2010) and has a population of over 639,951 people (Census of Population and Housing, 2011).

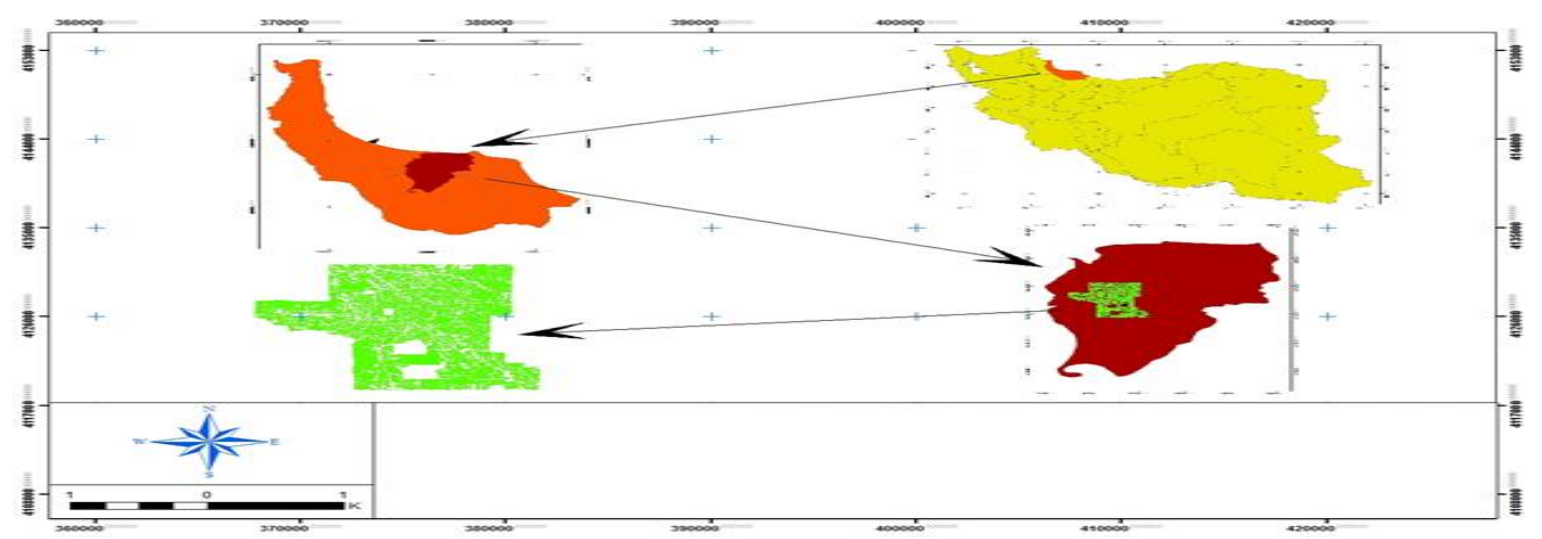

Figure 1 - The location of the study area in the Gilan province and the country.

\section{Research Methodology}

This study is a descriptive-survey research. From the organizations in this city, 50 organizations were selected randomly to determine the organization preparedness against the disasters: 19 cases were the main organizations of risk management, 18 cases were less relevant to the disaster management, and 13 cases were the organizations related to disaster management. A researcher-made questionnaire was used for collecting the required data. The questionnaire included demographic data, disaster management structure, planning section, training section, coordination section, and finally the background information. All study data were analyzed using SPSS software.

\section{Research findings}

The first hypothesis: the level of preparedness in "Rasht organizations" in dealing with natural disasters is very low. 
Table 1 - Descriptive data for test

\begin{tabular}{|l|l|l|l|l|}
\hline & No. & S.D.R & S.D & \\
\cline { 2 - 5 } Preparedness in organization & & & & \\
& 50 & 0.45 & 0.70 & 5.70 \\
\hline
\end{tabular}

Table 2 - Descriptive data for test

\begin{tabular}{|l|l|l|l|l|}
\hline \multicolumn{2}{|l|}{ Expected Mean } \\
\hline $\begin{array}{l}\text { Preparedness in } \\
\text { organization }\end{array}$ & Mean difference & Sig. & df & $\begin{array}{l}\text { Absolute } \\
\text { value }\end{array}$ \\
\cline { 2 - 6 } & 9.30 & 0.000 & 49 & 1.93 \\
\hline
\end{tabular}

\section{Interpretation and Description}

In order to assess the level of preparedness in Rasht organizations in dealing with natural disasters, a one-sample T-test was used. It compared the observed mean and standard mean. The tests output is shown in the above tables. According to data from the above tables, the test with absolute value of 1.93 , with a standard deviation of 0.70 , and with 49 degrees of freedom is significant at the 0.01 . Also, referring to the descriptive data of the test, it can be seen that the mean observed is much less than expected mean. So, this difference has led to the significance of the test. Also, the researchers analyzed data from the questionnaire with regard to their normal distribution and concluded that with over 99 percent of certainty, organizations in the Rasht are in the levels much lower than expected, in terms of preparedness against natural disasters. Therefore, the research hypothesis $\mathrm{H} 1$ is confirmed.

Considering the above hypothesis and analyzing the reasons for low levels of preparedness in the organizations of Rasht, the most important factors affecting the properties of crisis management components will be studied. According to researchers in this paper, several factors may affect on the explanation of this finding. Since all of the features and explanations of all the components may not be included in this brief article, we study the effects of organization's type in the form of a collateral hypothesis:

The second hypothesis: the level of organizations' preparedness in terms of crisis management components is different based on their type. 
Table 3 - Analytical data of second hypothesis

\begin{tabular}{|c|c|c|c|c|c|c|}
\hline $\begin{array}{l}\text { Component of crisis } \\
\text { management }\end{array}$ & $\begin{array}{l}\text { Data of } \\
\text { variance } \\
\text { Analysis }\end{array}$ & $\begin{array}{l}\text { Sum of } \\
\text { squares }\end{array}$ & $d f$ & S.M & $\begin{array}{c}\mathrm{F} \\
\text { Value }\end{array}$ & Sig. \\
\hline \multirow{3}{*}{$\begin{array}{l}\text { Management } \\
\text { structure }\end{array}$} & $\begin{array}{l}\text { Between } \\
\text { Groups }\end{array}$ & 1.660 & 2 & .830 & 3.773 & .030 \\
\hline & $\begin{array}{l}\text { Within } \\
\text { Groups }\end{array}$ & 10.340 & 47 & .220 & & \\
\hline & Total & 12.000 & 49 & & & \\
\hline \multirow{3}{*}{$\begin{array}{l}\text { Organizational } \\
\text { Preparedness }\end{array}$} & $\begin{array}{l}\text { Between } \\
\text { Groups }\end{array}$ & 29.914 & 2 & 14.957 & $\begin{array}{l}11.46 \\
7\end{array}$ & .000 \\
\hline & $\begin{array}{l}\text { Within } \\
\text { Groups }\end{array}$ & 61.306 & 47 & 1.304 & & \\
\hline & Total & 91.220 & 49 & & & \\
\hline \multirow{3}{*}{$\begin{array}{l}\text { Cooperation of } \\
\text { Organizations }\end{array}$} & $\begin{array}{l}\text { Between } \\
\text { Groups }\end{array}$ & 1.258 & 2 & .629 & .690 & .5 .6 \\
\hline & $\begin{array}{l}\text { Within } \\
\text { Groups }\end{array}$ & 42.822 & 47 & .911 & & \\
\hline & Total & 44.080 & 49 & & & \\
\hline \multirow{3}{*}{$\begin{array}{l}\text { Planning of } \\
\text { Organizations }\end{array}$} & $\begin{array}{l}\text { Between } \\
\text { Groups }\end{array}$ & .297 & 2 & .149 & 3.089 & .050 \\
\hline & $\begin{array}{l}\text { Within } \\
\text { Groups }\end{array}$ & 2.263 & 47 & .048 & & \\
\hline & Total & 2.560 & 49 & & & \\
\hline \multirow{3}{*}{$\begin{array}{l}\text { Coordination of } \\
\text { organizations }\end{array}$} & $\begin{array}{l}\text { Between } \\
\text { Groups }\end{array}$ & .409 & 2 & .452 & 2.826 & .049 \\
\hline & $\begin{array}{l}\text { Within } \\
\text { Groups }\end{array}$ & 7.516 & 47 & .160 & & \\
\hline & Total & 8.420 & 49 & & & \\
\hline Background & Between & 1.713 & 2 & .852 & 10.50 & .000 \\
\hline
\end{tabular}




\begin{tabular}{|l|l|l|l|l|l|l|}
\hline \multirow{2}{*}{$\begin{array}{l}\text { information in } \\
\text { organization }\end{array}$} & Groups & & & & 6 & \\
\cline { 2 - 8 } & $\begin{array}{l}\text { Within } \\
\text { Groups }\end{array}$ & 3.832 & 47 & .082 & & \\
\cline { 2 - 8 } & Total & 5.545 & 49 & & & \\
\hline \multirow{2}{*}{$\begin{array}{l}\text { Educational programs } \\
\text { of organizations }\end{array}$} & $\begin{array}{l}\text { Between } \\
\text { Groups }\end{array}$ & 7.132 & 2 & 3.566 & 3 & .000 \\
\cline { 2 - 8 } & $\begin{array}{l}\text { Within } \\
\text { Groups }\end{array}$ & 15.095 & 47 & .321 & & \\
\cline { 2 - 8 } & Total & 22.227 & 49 & & & \\
\hline
\end{tabular}

\section{Interpretation and Description}

Since the analysis of dependent variable -components of crisis management- difference is influenced by the multi-value independent variable of organization's type -original, relevant and less relevant, analysis of variance (ANOVA) test was used; the output is given in the above table. According to the above output, it can be seen that except the cooperation, the other components are significant at the level below 0.05. It can be inferred that the level of preparedness in organizations in terms of crisis management components is not independent from organization type. In other words, components of crisis management are influenced by organizations' type. According to the comparison of different organizations through post hoc test TUKEY, the influence has been higher in the main organizations; and they have a higher level of preparedness. But the difference was not significant between the next two (relevant and less relevant organizations) cases.

\section{Conclusions}

Based on the findings, the level of preparedness in organizations of Rasht has been much lower than expected. This finding is completely consistent with the findings of other studies in this field. Qasim Mousavi et.al (2009) stated the rehabilitation centers do not have adequate preparation against unexpected accidents. Hekmatkhah (2011) found that total mean of preparedness in hospitals against earthquakes is 20.07. In a study of hospital emergency wards preparedness in Philadelphia, Greenberg et al (2002) stated that it is very low-based on predetermined criteria. (Greenberg, et al, 2002)

Determining the level of preparedness among several hospitals in Los Angeles, Ah and RJ (2004) found that there is no objective measure in relation with preparedness level in the hospital and capacity of emergency wards in the hospital (AH \& RJ, 2004). Studying the effects of organizations' type on disaster management components, it can be inferred that there is direct and significant relationship between the preparedness in organizations and disaster management components. This means by reducing of preparedness, the amount of damage increases. Also, there is a low relationship between collaboration and crisis management 
components. This variable is not significant due to the influence of other variables. However, the final result of this study showed that studied organizations have a very low preparedness against unexpected disasters; investments should be provided on crisis management components. According to the results of this study, it is suggested that all employees of all organizations attend in first aid and rescue classes. All organizations should hold maneuvers at specified intervals to assess the preparedness level of different systems. An event program should be included in all governmental and non-governmental organizations.

\section{Acknowledgments}

We would like to appreciate the Payame Nour University, Guilan Branch for funding and supporting the project.

\section{References}

Abbaszadeh Shahri, Abbas, Foroozan, Farshid, Vahidi, Fardin., (2010), Nonlinear Analysis and evaluation of the response to the earthquake site in Rasht city, Construction monthly, 8, (73), October,9-2

AF, R., DM, C, (2004) Emergency department disaster preparedness: Identifying the Barriers. Annals of Emergency Medicine, 44.

AH, K., RJ, L, (2004) Hospital disaster preparedness in Los Angeles county, California. Annals of Emergency Medicine, 44.

Austin, D.W. (2012) Preparedness clusters: A research note on the disaster readiness of community-based organizations. Sociological Perspectives, 55, 2, pp. 383-393.

(5). Calderon, L. J. P. (2010) Importance of investing on emergency and disaster preparedness at country level. Procedia Social and Behavioral Sciences, 2, 7130-7136.

Duncan ,W., Yeager ,V. A., Rucks ,A. C,\& Ginter, P. M.(2011) .Surviving organizational disasters. Business Horizons , 54, 135-142.

Duarte, V.,\& Haynes, L. C.(2006). Disaster Preparedness: "As common as CPR". clinical simulation in nursing education , 2, 53-57

Greenberg, M.I. Jurgens, Sh. M.\&Gracely, Ed.J, (2002) Emergency department preparedness for the evaluation and treatment of victims of biologicalor chemical terrorist attack. Journal of Emergency Medicine, 22(3), pp. 273-278.

Hatami Nejad H, \& Janbaba Nejad MH. (2004) Disaster management for natural disasters (flood) in city. The Journal of Geographical sciences, 3: 58-74.

Hekmatkhah,A., Rahimi, H., KamaliAghdam, M., TaghaviShahri, S.M., Sadeghifar, J., Hamoozadeh, P.,(2011) Dealing with the earthquake risk assessment in hospitals of Urmia University of Medical sciences, Urmia .Journal of Nursing and Midwifery, Vol. I, Issue II, June and July, 200-208.

Hosseini, S. A., Hosseini, O., Hamghadam, N., Zahmatkesh, E., Delbari, S., (2013) Analysis of Response Indexes in Crisis Management with Emphasize on phases of before, during and after Crisis (The Case of Study: Rasht City). Universal Journal of Management and Social Sciences,3(6), 83-61. 
Hosseini, S. A., Hosseini,O., Hamghadam, N., Zahmatkesh, E., Delbari, S., (2013) Indigenizing of response indexes in crisis management in Iran (case study: Rasht city). singaporean journal of business economics, and management studies, 1(12),139-121.

Hosseini, S. A., Hosseini, O., Hamghadam, N., Zahmatkesh, E., Delbari, S., (2013) Localization of Temporary Settlement Areas in the City of Rasht by Using Model of Multi-Criteria Decision Making (MCDM). Journal of Contemporary Research in Business Copy Right, Institute of Interdisciplinary Business Research, MAY, 5(1), 1215-1227.

.Kangabam ,R.D., P.C. P, Kangabam ,M.(2012). Disaster Preparedness among the Resident Community- A Case Study of Rajiv Gandhi University, Itanagar, India. Internatlional Journal of environmental sciences , 2(3). 1632-1642

Mousavi, G., Makarem, A., Khankeh, H.R, Karimloo, M.,(2009) Evaluation of disaster preparedness of rehabilitation centers in Zanjan province in 1388.Journal of Emdad \& Nejat, No. 4, winter, pp.36.

Pearson, C. M., Mitroff, I. I. (1993) From Crisis Prone to Crisis Prepared: A Framework for Crisis Management. The Executive, Vol. 7, No. 1, pp. 48 -59.

Schwenk, m., Kluge, S., \& Jaroni, H. (2005) Toxicological aspects of preparedness and aftercare for chemical-incidents. Toxicology, 214, 232-248.

Sturm, T., Oh, E. (2010) Natural disasters as the end of the insurance industry? Scalar Competitive Strategies, Alternative Risk Transfers, and the Economic Crisis, Geoforum 41, 154163.

TFQCDM / WADEM: Health Disaster Management,(2002) Guidelines for Evaluation and Research in the "Utstein Style". Chapter 3: Overview and concepts. Prehosp Disast Med 17(Suppl 3):31-55.

Ziyari, Keramatolla, Shabani Kouchesfahani, Morteza. (2011), Disaster mitigation planning in Rasht based on Hyoko World Conference (2015-2005), the National Conference on Earthquake Vulnerability places and vital paths 